\title{
Kemampuan Berpikir Kritis pada Mata Pelajaran Ekonomi Siswa SMA Negeri 1 Cikarang Pusat
}

\author{
Maha Putra $^{1^{*}}$, Hari Mulyadi ${ }^{2}$, dan Eeng Ahman ${ }^{3}$ \\ ${ }^{1,2,3}$ Fakultas Pendidikan Ekonomi dan Bisnis, Universitas Pendidikan Indonesia \\ *E-mail: mahaputra@student.upi.edu
}

\begin{abstract}
Abstrak: Tujuan penelitian ini adalah untuk mengetahui kemampuan berpikir kritis pada mata pelajaran ekonomi SMA Negeri 1 Cikarang Pusat. Metode yang digunakan dalam penelitian ini adalah penelitian kuantitatif dimana data dikumpulkan dengan melakukan observasi, mengambil tes, dan melakukan wawancara. Dalam penelitian ini, peneliti memilih tiga kelas. Hasil penelitian menunjukkan bahwa kemampuan berpikir kritis siswa di SMA Ngeri 1 Cikarang pusat masih rendah. Hal ini terlihat dari hasil siswa dalam mengerjakan soal yang merujuk pada tingkat kemampuan berpikir kritis C4 dan C5 pada skor 20-60. Dari tiga kelas yang diamati, tidak ada siswa yang mendapat skor 80-100. Oleh karena itu, kemampuan berpikir kritis siswa di SMA Negeri 1 Cikarang Pusat secara khusus pada mata pelajaran ekonomi perlu ditingkatkan.
\end{abstract}

Kata Kunci: Kemampuan Berpikir Kritis, Pelajaran Ekonomi, Siswa SMA Negeri 1 Cikarang Pusat.

UTILITY: Jurnal IImiah Pendidikan dan Ekonomi

Website : http://journal.stkipnurulhuda.ac.id/index.php/utility

Permalink: https://journal.stkipnurulhuda.ac.id/index.php/utility/article/view/280

How to cite (APA): Putra, M., Mulyadi, H., \& Ahman, E. (2018, February 1). Kemampuan Berpikir Kritis pada Mata Pelajaran Ekonomi Siswa SMA Negeri 1 Cikarang Pusat. UTILITY: Jurnal IImiah Pendidikan Dan Ekonomi, 2(1), 10-18.

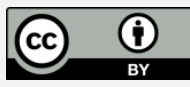

This is an open access article distributed under the terms of the Creative Commons Attribution 4.0 International License, which permits unrestricted use, distribution, and reproduction in any medium, provided the original work is properly cited.

\section{PENDAHULUAN}

Berpikir kritis merupakan suatu kemampuan penting yang harus dimiliki oleh siswa. Berpikir kritis mengadung aktivitas mental dalam hal memecahkan masalah yang menganalisis asumsi, memberi rasional, mengevaluasi, melakukan penyelidikan, dan mengambil keputusan. Sebuah studi terbaru yang dilakukan oleh DeAngelo et al., 2009:3 (dalam Huber \& Kuncel, 2015;2) 
melaporkan bahwa 99\% lembaga didukung untuk mengajar berpikir kritis sebagai tujuan paling penting pendidikan. Penelitian lain yang dilakukan oleh Nosich dan William (Han \& Brown, 2013) menunjukkan bahwa kemampuan untuk berpikir kritis sangat penting tidak hanya untuk keberhasilan siswa di kelas, tetapi sebagai keterampilan seumur hidup.

Menurut Watson \& Glaser (dalam Filsaime, 2008:60) memandang berpikir kritis sebagai sebuah gabungan sikap, pengetahuan, dan kecakapan. Survei nasional terbaru dari bisnis dan pemimpin nirlaba di Amerika Serikat menyatakan bahwa lebih dari $75 \%$ dari yang disurvei mengatakan mereka ingin lebih banyak penekanan dalam pendidikan berpikir kritis, memecahkan masalah yang kompleks dan komunikasi tertulis dan lisan (Hart penelitian Associates, 2013).(Bloch \& Spataro, 2014). Giancarlo and Facione (2007:5) mengemukakan bahwa "Critical Thinking as a disciplined, self-directed cognitive process leading to high quality decision and judgements through the analysis, assessment and reformulation of thinking" yang artinya berpikir kritis sebagai proses kognitif disiplin diri diarahkan menuju keputusan berkualitas tinggi dan penilaian melalui analsis, penilaian dan reformulasi pemikiran. Selanjutnyamenurut Walker (dalam Redhana, 2012)menyatakan bahwa keterampilan berpikir kritis merupakan suatu proses yang memungkinkan siswa memperoleh pengetahuan baru melalui proses pemecahan masalah dan kolaborasi.

John Dewey (Hasanah, 2016, hal 388) berpikir kritis adalah pertimbangan yang aktif, persistent (terus menerus), dan teliti mengenai sebuah keyakinan atau bentuk pengetahuan yang diterima begitu saja dipandang dari sudut alasanalasan yang mendukungnya dan kesimpulan-kesimpulan lanjutan yang menjadi kecenderungannya. Menurut Gülşah Külekçi1\& Esin Kumlu2 (2015:77) mengukapkan bahwa Critical thinking can be defined as the ability of thinkers to take charge of their own thinking and develop sound criteria and standards for analyzing and assessing their own thinking. Selanjutnya, Feldman (Feldman, 2010:4) juga menyatakan bahwa berpikir kritis mencakup tindakan untuk mengevaluasi situasi, masalah, atau argumen, dan memilih pola investigasi yang menghasilkan jawaban terbaik yang bisa di dapat.

Selanjutnya, penelitian dari UNESCO juga menunjukkan bahwa pentingnya berpikir kritis sebenarnya telah dibuktikan semenjak zaman Socrates. Pada kegiatan ilmiah juga mempersyaratkan pemikiran yang kritis, 
sangat mengejutkan melihat sedikitnya lulusan mahasiswa yang dapat menunjukkan kemampuan ini. Ketidakmampuan output pembelajaran untuk berpikir kritis telah menjadi isu nasional yang harus segera ditanggulangi.

Pemerintah dan kalangan lembaga pendidikan harus lebih fokus kepada kualitas pendidikan yang saat ini dinilai masih jalan di tempat. Hal ini ditunjukkan dengan hasil studi PISA (Program for International Student Assessment) tahun 2015 yang menunjukkan Indonesia baru bisa menduduki peringkat 69 dari 76 negara. Sedangkan dari hasil studi TIMSS (Trends in International Mathematics and Science Study), menurut Ruri, menunjukkan siswa Indonesia berada pada ranking 36 dari 49 negara dalam hal melakukan prosedur ilmiah. "Dalam 10 tahun terakhir ini hasil PISA dan TIMSS selalu beriringan dan berjalan di tempat". Hasil survei tersebut mencerminkan siswa indonesia belum mampu memecahkan soal yang membutuhkan keterampilan berpikir tingkat tinggi yang juga mencakup keterampilan berpikir kritis.

Siswa sangat perlu memiliki keterampilan berpikir kritis, karena keterampilan berpikir kritis tersebut sangat membantu siswa dalam melakukan pengambilan keputusan. Hal tersebut didukung oleh fisher (dalam Javad, Mir, \& Rousta, 2013:2) yang menyatakan bahwa berpikir kritis akan lebih baik diartikan sebagai keahlian dan keaktifan dalam mengamati dan mengevaluasi berbagai informasi yang melibatkan kemampuan berpikir tingkat tinggi". Menurut (Costa, 1985:54) kemampuan dalam berpikir kritis akan memberikan arahan yang lebih tepat dalam berpikir, bekerja, dan membantu lebih akurat dalam menentukan keterkaitan sesuatu dengan yang lainya. Menurut(Johnson, 2008:185)tujuan dari berpikir kritis adalah untuk mencapai pemahaman yang mendalam. Berdasarkan uraian di atas, peneliti tertarik melakukan penelitian tentang kemampuan berpikir kritis siswa di SMA Cikarang.

\section{METODE}

Penelitian ini merupakan penelitian kuantittaif. Penelitian kuantitatif didasari oleh filsafat positivissme yang menekankan fenomena-fenomena objektif dan dikaji secara kuantitatif (Sukmadinata, 2012, hlm.53). Selain itu, penelitian ini menggunakan data statistik sebagai data utama penelitian dalam rangka menguji teori yang digunakan. 


\section{HASIL DAN PEMBAHASAN}

Berdasarkan hasil survey yang dilakukan, peneliti mendapati hasil nilai rata-rata ujian akhir semester ganjil kelas XI IIS yang masih dibawah standar kriteria kelulusan minimal (KKM). Berikut ini presentase nilai rata-rata ujian akhir semester ganjil sebagai berikut:

Tabel 1. Nilai Rata-Rata Ujian Akhir Semester Ganjil Mata pelajaran Ekonomi Kelas XI IIS SMA Negeri 1 Cikarang Pusat

\begin{tabular}{cccc}
\hline No & Kelas & Nilai Rata-Rata & KKM \\
1 & XI IIS 1 & 70,56 & 75 \\
2 & XI IIS 2 & 72,91 & 75 \\
3 & XI IIS 3 & 69,66 & 75 \\
4 & XI IIS 4 & 71,20 & 75 \\
\hline
\end{tabular}

Sumber: SMA Negeri 1 Cikarang Pusat

Hasil belajar peserta didik dilihat dari tabel 1.1 terlihat bahwa rendahnya hasil belajar siswa pada mata pelajaran ekonomi kelas XI IIS 1 sampai dengan XI IIS 4 SMA Negeri 1 Cikarang Pusat nilai rata-rata masih dibawah KKM. Dalam hal ini, diperlukan upaya untuk meningkatkan kemampuan berpikir kritis siswa melalui hasil belajar siswa. Untuk mengukur kemampuan berpikir kritis peserta didik tidak hanya dilihat dari perolehan nilai peserta didik saja. Akan tetapi dapat dilihat dari soal-soal yang digunakan dalam ujian akhir semester ganjil. Berikut ini hasil analisis soal ujian akhir semester ganjil untuk mata pelajaran ekonomi.

Tabel 2. Analisis Soal Ujian Akhir Semester Ganjil Mata Pelajaran Ekonomi Kelas XI IIS SMA Negeril Cikarang Pusat Tahun Pelajaran 2016/2017

\begin{tabular}{lllllll}
\hline $\begin{array}{c}\text { Proses } \\
\text { Kognitif }\end{array}$ & C1 & C2 & C3 & C4 & C5 & C6 \\
\hline $\begin{array}{l}\text { Jumlah soal } \\
\begin{array}{l}\text { UAS (pilihan } \\
\text { ganda 50 soal) }\end{array}\end{array}$ & 20 & 15 & 15 & - & - & - \\
\hline
\end{tabular}

Sumber: SMA Negeri 1 Cikarang Pusat

Berdasarkan data diatas maka dapat dilihat bahwa tingkat kemampuan berpikir kritis peserta didik di SMA Negeri 1 Cikarang Pusat masih rendah. Hal ini dapat dibuktikan dengan nilai rata-rata kelas yang belum mencapai standar 
Kriteria Ketuntasan Minimal atau KKM. Serta dalam pembuatan soal-soal ujian akhir semester tersebut didapat tidak ada soal yang menggunakan ranah kognitif C4, C5. Sedangkan soal yang dapat digunakan untuk mengukur kemampuan berpikir krtitis didik yaitu soal dengan ranah kognitif C4 dan C5. Karena menurut Bloom (dalam Gunawan \& Palupi, 2008:18) ranah kognitif C4 (Analisis), C5 (Sintesis), C6 (Mencipta) merupakan high thinking level. Kemampuan berpikir kritis merupakan salah satu dari kemampuan berpikir tingkat tinggi. Kemampuan berpikir siswa dapat dibedakan menjadi 6 tingkatan yaitu mengingat (remembering), memahami (understanding), menerapkan (applying), menganalisis (analysing), menilai (evaluating), dan mencipta (creating). Kemampuan berpikir tersebut dibagi menjadi dua kelompok, yaitu kemampuan berpikir tingkat rendah (lower order thinking skills) meliputi mengingat/C1, memahami/C-2 dan menerapkan/C-3 dan kemampuan berpikir tingkat tinggi (higher order thinking skills) meliputi menganalisis/C-4, menilai/C-5 dan mencipta/C-6). Pengelompokan tingkat berpikir dalam ranah kognitif tersebut berdasarkan klasifikasi tingkat berpikir pada "Revisi Taksonomi Bloom (A Revision of Bloom's Taxonomy)".Hal ini sesuai dengan pendapat Tsui (Dalam Behar-horenstein \& Niu, 2011:1) "Teaching students higher-order cognitive skills, including critical thinking.Oleh karena itu dapat diketahui bahwa peserta didik masih memiliki kemampuan berpikir kritis yang rendah.

Untuk memperkuat hasil temuan wawancara maka dilakukan penelitian dengan membagikan soal yang dibuat dengan kriteria indikator berpikir kritis yang di isi oleh peserta kelas XI IIS 3, hal ini dilakukan untuk mengetahui berapa persen jumlah siswa yang mampu menjawab soal dengan indikator berpikir kritis, maka dibuat tabel rekapitulasi presentasi sebagai berikut:

Tabel 3. Rekapitulasi Skor Kemampuan Berpikir Kritis Siswa Kelas XI IIS 2 SMAN 1 Cikarang Pusat Tahun Pelajaran 2016/2017

\begin{tabular}{ccc}
\hline Skor & Jumlah Peserta Didik & Presentase (\%) \\
\hline 0 & - & - \\
10 & - & - \\
20 & 6 & 14 \\
30 & 8 & 19 \\
40 & 12 & 29 \\
50 & 16 & 33 \\
\hline
\end{tabular}




\begin{tabular}{ccc}
\hline Skor & Jumlah Peserta Didik & Presentase (\%) \\
\hline 60 & 1 & 2 \\
70 & - & 2 \\
80 & - & - \\
90 & - & - \\
100 & - & - \\
Jumlah & 42 & 100 \\
\hline
\end{tabular}

Sumber: Hasil Pra Penelitian (diolah)

Berdasarkan data dari tabel 1.3 yang merujuk pada indikator berpikir kritis tidak ada siswa yang mencapai skor ideal dari 80-100. Peserta didik hanya mampu mengerjakan soal dengan memperoleh skor dibawah ideal yakni berada pada rentan 20-60. Siswa terbanyak hanya mampu menjawab dengan skor 50 mencapai 33\% dari jumlah siswa. Perolehan data diatas dapat menggambarkan bahwa siswa belum mampu mencapai kemampuan berpikir kritis. Permasalahan dalam peningkatan kemampuan berpikir kritis siswa inilah yang menjadi permasalahan guru dalam membantu siswa untuk mencapai kemampuan berpikir kritis

Tabel 4. Rekapitulasi Skor Kemampuan Berpikir Kritis Siswa Kelas XI IIS 3 SMAN 1 Cikarang Pusat Tahun Pelajaran 2016/2017

\begin{tabular}{ccc}
\hline Skor & Jumlah Peserta Didik & Presentase (\%) \\
\hline 0 & - & - \\
10 & - & - \\
20 & 9 & 20 \\
30 & 5 & 11 \\
40 & 16 & 36 \\
50 & 13 & 31 \\
60 & 1 & 2 \\
70 & - & - \\
80 & - & - \\
90 & - & - \\
100 & - & - \\
Jumlah & 44 & 100 \\
\hline
\end{tabular}

Sumber: Hasil Pra Penelitian (diolah)

Berdasarkan data dari tabel 1.3 yang merujuk pada indikator berpikir kritis tidak ada siswa yang mencapai skor ideal dari 80-100. Peserta didik hanya mampu mengerjakan soal dengan memperoleh skor dibawah ideal yakni berada pada rentan 20-70. Siswa terbanyak hanya mampu menjawab dengan skor 40 
mencapai 36\% dari jumlah siswa. Perolehan data diatas dapat menggambarkan bahwa siswa belum mampu mencapai kemampuan berpikir kritis. Permasalahan dalam peningkatan kemampuan berpikir kritis siswa inilah yang menjadi permasalahan guru dalam membantu siswa untuk mencapai kemampuan berpikir kritis.

Tabel 4. Rekapitulasi Skor Kemampuan Berpikir Kritis Siswa Kelas XI IIS 4 SMAN 1 Cikarang Pusat Tahun Pelajaran 2016/2017

\begin{tabular}{ccc}
\hline Skor & Jumlah Peserta Didik & Presentase (\%) \\
0 & - & - \\
10 & - & - \\
20 & 11 & 24 \\
30 & 9 & 20 \\
40 & 14 & 31 \\
50 & 10 & 22 \\
60 & 1 & 2 \\
70 & - & - \\
80 & - & - \\
90 & - & - \\
100 & - & - \\
Jumlah & 45 & 100 \\
\hline
\end{tabular}

Sumber: Hasil Penelitian (diolah)

Berdasarkan data dari tabel 1.3 yang merujuk pada indikator berpikir kritis tidak ada siswa yang mencapai skor ideal dari 80-100. Peserta didik hanya mampu mengerjakan soal dengan memperoleh skor dibawah ideal yakni berada pada rentan 20-70. Siswa terbanyak hanya mampu menjawab dengan skor 40 mencapai 31\% dari jumlah siswa. Perolehan data diatas dapat menggambarkan bahwa siswa belum mampu mencapai kemampuan berpikir kritis. Permasalahan dalam peningkatan kemampuan berpikir kritis siswa inilah yang menjadi permasalahan guru dalam membantu siswa untuk mencapai kemampuan berpikir kritis.

Hasil observasi lebih lanjut yang dilakukan dengan guru mata pelajaran ekonomi kelas XI IIS di SMA Negeri 1 Cikarang Pusat diperoleh informasi bahwa pembelajaran yang dilakukan pada mata pelajaran ekonomi tersebut saat ini masih tergolong monoton. Artinya, metode pembelajaran, bahan ajar, maupun strategi pembelajaran yang digunakan masih terhitung konvensional. Proses pembelajaran masih didominasi oleh guru sehingga peserta didik kurang 
berperan aktif dalam pembelajaran. Watts (dalam Finkelstein Neal \& Dr. Thomas Hanson, 2011:1) mengatakan bahwa semua pendidikan menenggah tentunya akan sangat membutuhkan mata pelajaran ekonomi. Namun, faktanya dalam proses pembelajaran guru hanya menggunakan teks yang tidak didukung dengan proses pembelajaran yang berkualitas.

\section{SIMPULAN}

Berdasarkan penelitian ini, keterampilan berpikir kritis siswa di SMA khususnya kelas XI IIS.2, XII IIS.3, dan XII IIS.4 butuh ditingkatkan sebab keterampilan berpikir kritis mereka pada mata pelajaran ekonomi masih rendah. Hal ini dibuktikan dengan totala skor pada tes yang diberikan oleh guru hanya 40-50. Oleh karena itu, guru harus meningkatkan hal ini dengan berbagai upaya seperti mengimplementasikan tes dengan standar berpikir kritis yang tinggi dan mengajar dengan metode yang bervariasi sehingga siswa menjadi lebih semangat dan termotivasi dalam belajar.

\section{REFERENSI}

Bloch, J., \& Spataro, S. E. (2014). Cultivating Critical-Thinking Dispositions.

Costa, A. L. (1985). Developing Minds, A Resource Book For Teaching Thinking. Virginia: Ascd.

Feldman, A. D. (2010). Berpikir Kritis:Strategi Untuk Pengambilan Keputusan. Jakarta Barat: Pt Indeks.

Filsaime. (2008). Menguak Rahasia Berpikir Kritis Dan Kreatif. Jakarta: Prestasi Pustaka.

Gülşah Külekçi1 \& Esin Kumlu2. (2015). International Journal Of Language Academy Developing Critical Thinking Skills In English Language Teaching Classes. International Journal Of Language Academy, 3, 7690.

Han, H. S., \& Brown, E. T. (2013). Effects Of Critical Thinking Intervention For Early Childhood Teacher Candidates. Teacher Educator, 48 (February 2015), 110-127. 
Hasanah, U. (2016). Pengaruh Model Pembelajaran Dan Kemampuan Berpikir Kritis Terhadap Hasil Belajar Ipa Kelas V Sd Di Kelurahan Menteng, Jakarta Pusat Uswatun Hasanah Penguasaan Sains Di Indonesia Masuk Ke Mutu Penguasaan Sains Di Dalam Kategori Rendah . Tentu Hal Ini Menj. Jurnal Pendidikan Dasar Universitas Negeri Jakarta, 7, 1-12.

Huber, C. R., \& Kuncel, N. R. (2015). Does College Teach Critical Thinking? A Meta-Analysis. Review Of Educational Research, (1987), 1-38.

Javad, S., Mir, G., \& Rousta, S. N. (2013). The Effect Of Problem-Based Learning On Critical Thinking Ability Of Iranian Efl Students. Journal Of Academic And Applied Studies, 3(July), 1-14.

Johnson, E. B. (2008). Contextual Teaching \& Learning: Menjadikan Kegiatan Belajar-Mengajar Mengasyikkan Dan Bermakna. Bandung: Mizan Media Utama.

Redhana, I. W. (2012). Model Pembelajaran Berbasis Masalah Dan Pertanyaan Socratik Untuk Meningkatkan Keterampilan Berpikir Kritis Siswa. Fmipa Universitas Pendidikan Ganesha, 351-365.

Sukmadinata, N.S. (2012). Metode penelitian pendidikan. Bandung: PT Remaja Rosdakarya.

Throughout The Business Curriculum. Business And Professional Communication Quarterly, 77(3), 249-265. 